\title{
A Pine with Six Hands: Introduction
}

https://doi.org/10.51897/interalia/ZPOT8045

Mathias Foit

Freie Universität Berlin

The extraordinary story of Countess Dina Alma de Paradeda, who spent the final weeks of her life in Breslau (modern-day Wrocław, which, at the time, lay within the borders of the German Empire), was introduced to the German-speaking world by Jens Dobler. In 2010, Dobler republished and appended an afterword to a more-than-one-hundred-year-old novel by Walter Homann, Tagebuch einer männlichen Braut [The Diary of a Male Bride], which had been inspired by incidents in de Paradeda's life. The afterword catalogues the few definite facts as well as the unexplained mysteries and conjectures concerning the biography of the self-styled comtesse. It remains unknown whether Dina, born as Alfred (or Alfredo) H. (or P.?) and came of an aristocratic background; who her biological father was and if he really was a Spanish consul in Rio de Janeiro; what the nature of her relationship with her stepfather (a German doctor who had married a Brazilian widow) was; whether or not Dina's fiancé knew her secret and if he was possibly pressured into breaking the engagement by his family; and finally, who and why reported the countess to the police. Certain, however, is the fact that the tragic history of one of the first identifiable trans* individuals in Central Europe inflamed public opinion not only in Germany, but also in the United States and New Zealand. In addition to numerous press articles, frequently contradicting one another and thus making it more difficult to reconstruct those events, at least two novels inspired by the predicaments of the "Breslau male bride" appeared in print. The fact that they came out just months following the scandal caused by her suicidal death clearly attests to the wide publicity and popularity this story enjoyed. I myself came across it while doing doctoral research on the life of queer people in the late-nineteenth and early-twentieth century in German territories that passed under Polish rule in 1945.

Although more than a century has passed since the Breslau scandal, non-heteronormative, especially trans*, residents still find it hard to function in public in the same city, and generally in Poland. They are still met not only with a lack of empathy and goodwill, but also, more and more often (and with an increasingly frightening intensity), with aggression, hate and violence. The story of Dina, who valued aligning one's life with one's identity more than life itself, takes on a special meaning today, in the year 2020, which sees more incidents of suicide among queer individuals, especially teenagers, who cannot bear the pervasive atmosphere of intimidation and exclusion. Tellingly, the following fairy tale, written by the artist Liliana Piskorska, was performed on Wzgórze Słowiańskie [Słowiańskie Hill] in a Wrocław park by the drag queen artist and activist Twoja Stara on August 8, one day after the brutal suppression of a protest against the arrest of Margot, activist and co-founder of Stop Bzdurom [Stop the Nonsense], and the incarceration of almost 50 other participants in the demonstration. In this context, Liliana Piskorska's narrative has an even stronger resonance as it speaks out against present- 
day attempts at erasing queer people from the public consciousness or even eradicating them. It is a voice demanding that the validity of their lives be acknowledged, and their freedom and dignity be respected. The performance and the exhibition documenting it, which was housed in August 2020 in Złoty Kiosk-a unique, cube-shaped art gallery sized $2.5 \times 2.5 \times 2.5 \mathrm{~m}$-are part of a cultural programme celebrating the $50^{\text {th }}$ anniversary of Sympozjum Plastyczne Wrocław ' 70 [The ' 70 Wrocław Art Symposium], commemorated by an exhibition titled New Normativity at the Wrocław Contemporary Museum (MWW).

Translation: Ewa Bodal. Editing: Dominika Ferens.

[For photographic documentation of the performance, see pp. 72, 75-79, 97-101.] 